\title{
Analisis Logam Fe dengan Teknik Voltammetri Pelucutan Anodik Pulsa Diferensial dalam Tanaman Pakcoy dari Perkebunan Sayur Bedugul Bali
}

\author{
Irdhawati, Rosanti Suryani, Tince Mbatu, Emmy Sahara \\ Program Studi Kimia, Fakultas Matematika dan Ilmu Pengetahuan Alam, Universitas Udayana \\ Jl. By Pass Ngurah Rai, Kampus Bukit Jimbaran Bali, Indonesia, 80361 Indonesia
}

Email:irdhawati@unud.ac.id

Received: April 2018; Revised: July 2018; Accepted: November 2018; Available Online: November 2018

\begin{abstract}
Abstrak
Tanaman pakcoy merupakan salah satu sayur yang banyak diminati masyarakat. Penggunaan pupuk dan pestisida sintesis yang mengandung logam berat dapat menyebabkan pakcoy tercemar logam berat. Penelitian ini bertujuan untuk mengetahui validitas pengukuran dan kadar logam Fe pada sampel pakcoy menggunakan teknik voltammetri pelucutan anodik pulsa diferensial. Elektrode kerja yang digunakan berupa cakram platina, elektrode pembanding $\mathrm{Ag} / \mathrm{AgCl}$, dan elektrode pembantu kawat platina. Hasil optimasi pengukuran larutan standar $\mathrm{Fe}(\mathrm{III})$ terdiri atas waktu deposisi optimum 70 detik, laju pindai optimum $10 \mathrm{mV} / \mathrm{s}$, serta potensial deposisi optimum $0.47 \mathrm{~V}$. Hasil pengukuran validitas larutan standar Fe(III) terdiri atas rentang konsentrasi linier dari $50 \mathrm{ppb} \sim 500$ ppb pada potensial puncak $-500 \mathrm{mV}$, dengan nilai koefisien korelasi 0.9977 . Limit deteksi $50.18 \mathrm{ppb}$. Keberulangan pengukuran Fe(III) sebanyak 10 kali memiliki rasio Horwitz kurang dari 2. Persen perolehan kembali $100.26 \% \pm 0.27 \%$. Hasil pengukuran rata-rata Fe(III) pada sampel tanaman pakcoy dari lima titik lokasi sampling sebesar $3.82 \pm 0.29 \mathrm{ppm}$, yang tidak melebihi kadar maksimum SNI yang diperkenankan yaitu $5.0 \mathrm{ppm}$.
\end{abstract}

Kata kunci: Besi, pakcoy, voltammetri pelucutan anodik pulsa diferensial.

\begin{abstract}
Pakcoy is one of the most popular vegetable. The use of synthetic fertilizers and pesticides contain heavy metals can contaminate pakcoy vegetable. This research aims to determine the validity of measurements and concentration of $\mathrm{Fe}$ in pakcoy using differential pulse anodic stripping voltammetry technique. The working, reference, and counter electrodes were platinum disk, $\mathrm{Ag} / \mathrm{AgCl}$, and $\mathrm{Pt}$ wire, respectively. The optimum measurement results of the standard solutions of Fe(III) obtained the optimum deposition time was 70 seconds, the optimum scan rate was $10 \mathrm{mV} / \mathrm{s}$, and the optimum deposition potential at $-0.47 \mathrm{~V}$. A linear concentration of standard solution of $\mathrm{Fe}$ (III) observed at the range of $50 \mathrm{ppb} 500 \mathrm{ppb}$, with correlation coefficient 0.9954. Limit of detection was $50.18 \mathrm{ppb}$. The repetition of 10 times measurements had a Horwitz ratio of less than 2. Percent recovery was $100.26 \% \pm 0.27 \%$. The average of Fe(III) concentration in the samples from 5 (five) locations of the pakcoy sampling contains $3.82 \pm 0.29 \mathrm{ppm}$, less than SNI treshold line of $5.0 \mathrm{ppm}$.
\end{abstract}

Keywords: Differential pulse anodic stripping voltammetry, iron, pakcoy.

DOI: http://10.15408/jkv.v4i2.7588

\section{PENDAHULUAN}

Tanaman pakcoy merupakan salah satu sayur yang banyak diminati masyarakat. Pakcoy merupakan tanaman sayur berumur pendek serta dapat ditanam pada berbagai musim sehingga dapat dibudidayakan sepanjang tahun. Pemenuhan kebutuhan sayuran di Bali berasal dari daerah Candikuning, Bedugul yang merupakan sentra penghasil sayuran. Tingginya permintaan pasar akan sayuran ini menyebabkan petani di daerah tersebut menanam pakcoy sepanjang tahun. 
Untuk menjaga kualitas, meningkatkan hasil produksi, dan meminimalisir gagal panen tanaman pakcoy, para petani menggunakan pupuk dan pestisida sintesis secara rutin. Penggunaan pupuk dan pestisida yang berlebihan secara tidak langsung dapat mencemari tanah dan tanaman karena pestisida dan pupuk mengandung sejumlah logam dalam konsentrasi yang berbeda-beda (Alloway, 2013). Adanya logam berat dalam tanah dapat menurunkan kualitas hasil produksi dan dapat terserap oleh tanaman kemudian akan masuk ke dalam siklus rantai makanan dan membahayakan kesehatan masyarakat. Logam berat dapat terakumulasi dalam tubuh manusia dan jika telah melebihi kadar maksimum akan menimbulkan efek toksik (Alloway, 2013; Priyono, 2006).

Salah satu logam esensial yang dibutuhkan oleh tubuh manusia adalah zat besi. Zat besi sangat reaktif, teroksidasi dengan adanya oksigen sehingga dapat merusak komponen biologis esensial lainnya seperti lemak dan protein. Teknik yang dapat digunakan untuk menganalisis logam adalah voltammetri pelucutan anodik, yaitu teknik voltammetri pelucutan anodik pulsa diferensial (Differential Pulse Anodic Stripping Voltammetry-DPASV). Teknik ini telah dilaporkan memiliki limit deteksi rendah, penyiapan sampel tidak sulit, waktu analisis cepat, kadar logam dalam sampel dapat ditentukan secara simultan, dan biaya yang relatif murah (Settle, 1997; Gunzler and Williams, 2001; Zosky, 2007;Arduini et al., 2010). Kinerja teknik voltammetri dipengaruhi oleh elektrode kerja. Elektrode kerja platina memiliki sifat yang sangat stabil, bersifat inert, dan mudah dibentuk.

Untuk menguji metode voltammetri yang digunakan dalam penelitian ini, maka perlu dilakukan validasi terhadap beberapa parameter, diantaranya: rentang konsentrasi linier, limit deteksi, keberulangan pengukuran, dan persen perolehan kembali. Parameter tersebut menjadi ukuran dari kemampuan metode untuk mengidentifikasi analit. Pada penelitian ini, analisis kadar logam $\mathrm{Fe}$ dalam tanaman pakcoy dilakukan menggunakan teknik voltammetri pelucutan anodik pulsa diferensial, dengan elektrode kerja berupa cakram platina dengan menerapkan kondisi kerja yang optimum. Pemilihan logam $\mathrm{Fe}$ karena bersifat esensial, diperlukan oleh tubuh dalam proses metabolisme, namun dalam jumlah yang berlebihan dapat membahayakan kesehatan.

\section{METODE PENELITIAN}

Alat yang digunakan yaitu: potensiostat Ingsens 1030, adaptor, neraca analitik Shimadzu Tipe ATY224, elektrode kerja cakram platina diameter 2,0 $\mathrm{mm}$ dari Bio Analytical System (BAS), elektrode pembanding $\mathrm{Ag} / \mathrm{AgCl}$ (handmade) dengan nilai koefisien difusi yang dapat diterima, elektrode pembantu kawat platina diameter 0,5 $\mathrm{mM}$, pipet mikro (Socorex), pengaduk magnetik, polishing sheet, oven (Memmert), pelat pemanas, filler, mortar, alu, dan peralatan gelas.

Bahan-bahan yang digunakan yaitu $\mathrm{Fe}\left(\mathrm{NO}_{3}\right)_{3} .9 \mathrm{H}_{2} \mathrm{O}, \mathrm{K}_{3} \mathrm{Fe}(\mathrm{CN})_{6}, \mathrm{~K}_{4} \mathrm{Fe}(\mathrm{CN})_{6} .3 \mathrm{H}_{2} \mathrm{O}$, aqua regia (campuran $\mathrm{HNO}_{3}: \mathrm{HCl}=1: 3$ ), $\mathrm{KCl}$, $\mathrm{HNO}_{3}, \mathrm{HCl}$, bubur alumina $0.05 \mu \mathrm{m}$, aseton, aquabides. Semua bahan kimia yang digunakan dibeli dari Merck dengan kualitas pro analisis, tanpa pemurnian tambahan.

\section{Optimasi Kondisi Pengukuran}

Pengukuran dilakukan pada larutan standar logam Fe dengan teknik DPASV.

\section{a) Penentuan waktu deposisi optimum}

Pengukuran dilakukan dengan variasi waktu deposisi 40; 70;100; 130; dan 160 detik, kecepatan pengadukan $2000 \mathrm{rpm}$, potensial deposisi $-1.2 \mathrm{~V}$, rentang potensial pengukuran $-1.4 \mathrm{~V}$ sampai $+0.4 \mathrm{~V}$, dan waktu diam (quite time) 25 detik.

\section{b) Penentuan laju pindai optimum}

Variasi laju pindai yaitu $5 ; 6 ; 10 ; 15$; dan $30 \mathrm{mV} / \mathrm{s}$, kecepatan pengadukan $2000 \mathrm{rpm}$ selama waktu deposisi optimum, potensial deposisi $-1.2 \mathrm{~V}$, rentang potensial pengukuran $1.4 \mathrm{~V}$ sampai $+0.4 \mathrm{~V}$, waktu diam 25 detik.

\section{c) Penentuan potensial deposisi optimum}

Variasi potensial deposisi $-0.17 ;-0.27$; $-0.37 ;-0.47,-0.57 \mathrm{mV}$, kecepatan pengadukan $2000 \mathrm{rpm}$ selama waktu deposisi optimum dan laju pindai optimum, rentang potensial pengukuran $-1.4 \mathrm{~V}$ sampai $+0.4 \mathrm{~V}$, waktu diam 25 detik.

\section{Validasi Pengukuran}

a) Penentuan rentang konsentrasi linier

Rentang konsentrasi linier ditentukan dengan mengukur arus puncak dari larutan 
standar logam dengan konsentrasi: 5, 10, 25, 50, 100, 250, 500, 1000, 1500, 2000, $2500 \mathrm{ppb}$ dalam $\mathrm{HNO}_{3} \quad 0.1 \mathrm{M}$. Selanjutnya dibuat plot antara arus yang terukur (y) terhadap konsentrasi larutan (x).

\section{b) Penentuan limit deteksi}

Limit deteksi ditentukan berdasarkan data rentang konsentrasi linier dan perhitungan menggunakan persamaan 1, 2, dan 3 (Miller and Miller, 2010).

$$
\begin{aligned}
& \mathbf{S}_{y / x}=\sqrt{\frac{\sum\left(\mathrm{y}_{\mathrm{i}}-\hat{\mathrm{y}}_{\mathrm{i}}\right)^{2}}{(\mathrm{n}-2)}} \\
& \hat{y}_{i}=a+b x \\
& \mathbf{L o D}=\frac{3 \mathbf{x S}_{\mathrm{y} / \mathbf{x}}}{\mathbf{b}}
\end{aligned}
$$

Keterangan: $\mathrm{S}_{y / x}=$ standar deviasi terhadap garis linier, $\mathrm{b}=$ slope/kemiringan, $\mathrm{LoD}=$ limit deteksi a $=$ intersep, nilai $\hat{y}_{i}$ pada standar deviasi diperoleh dari memasukkan nilai $\mathrm{x}$ dalam persamaan regresi linier.

\section{c) Penentuan keberulangan pengukuran (ketelitian) \\ Ketelitian pengukuran ditentukan} dengan mengukur arus yang dihasilkan oleh larutan standar $\mathrm{Fe}(\mathrm{III}) 500 \mathrm{ppb}$ dalam $\mathrm{HNO}_{3}$ $0.1 \mathrm{M}$ pada kondisi pengukuran optimum yang dilakukan secara berulang sebanyak 10 kali pengukuran.

\section{d) Penentuan persen perolehan kembali (\% recovery)}

Larutan standar $\mathrm{Fe}(\mathrm{III})$ dengan konsentrasi 500 ppb dibuat sebanyak tiga kali. Arus puncak larutan tersebut diukur kemudian diplot ke dalam kurva kalibrasi sehingga diperoleh konsentrasi Fe(III). Konsentrasi hasil pengukuran kemudian dibandingkan dengan konsentrasi larutan standar sebenarnya yang dibuat.

\section{Preparasi dan pengukuran konsentrasi Fe(III) dalam sampel \\ Sampel pakcoy dicuci dengan air} bersih, dibilas dengan aquabides, dan dikeringkan selama 24 jam pada suhu kamar. Sampel dipotong, ditimbang, dikeringkan dalam oven pengering suhu $80{ }^{\circ} \mathrm{C}$, lalu ditimbang lagi hingga diperoleh massa konstan, sehingga kadar air sampel dapat ditentukan. Sampel kering dihaluskan, lalu ditimbang 5 gram dan didestruksi menggunakan aqua regia, dan filtrat hasil penyaringan diencerkan hingga $25.0 \mathrm{~mL}$.

Penentuan konsentrasi $\mathrm{Fe}$ dalam sampel menggunakan metode adisi standar. Sebanyak $1.0 \mathrm{~mL}$ larutan sampel hasil destruksi dimasukkan masing-masing ke dalam lima buah labu ukur $10 \mathrm{~mL}$ dengan komposisi volume larutan standar sebanyak $0 ; 1 ; 1.5 ; 2.5$; dan $4 \mathrm{~mL}$, ditambahkan $\mathrm{HNO}_{3} 0.1 \mathrm{M}$ hingga tanda batas, dan dikocok hingga homogen. Pengukuran dilakukan pada kondisi waktu deposisi, laju pindai, dan potensial deposisi optimum.

\section{HASIL DAN PEMBAHASAN Karakterisasi Elektrode Pembanding Ag/AgCl}

Karakterisasi elektrode pembanding $\mathrm{Ag} / \mathrm{AgCl}$ bertujuan untuk mengetahui nilai koefisien difusi (D), sehingga dapat diketahui elektrode pembanding $\mathrm{Ag} / \mathrm{AgCl}$ yang telah dibuat layak digunakan untuk pengukuran. Hasil perhitungan nilai koefisien difusi (D) dengan variasi laju pindai pada larutan $\mathrm{K}_{3} \mathrm{Fe}(\mathrm{CN})_{6}$ sebesar $1.0431 \times 10^{-5} \mathrm{~cm}^{2} / \mathrm{s}$, dan pada larutan $\mathrm{K}_{4} \mathrm{Fe}(\mathrm{CN})_{6}$ sebesar $3.5681 \times 10^{-5}$ $\mathrm{cm}^{2} / \mathrm{s}$. Hasil perhitungan nilai koefisien difusi (D) dengan variasi konsentrasi pada larutan $\mathrm{K}_{3} \mathrm{Fe}(\mathrm{CN})_{6}$ sebesar $5.3283 \times 10^{-6} \mathrm{~cm}^{2} / \mathrm{s}$, dan pada larutan $\mathrm{K}_{4} \mathrm{Fe}(\mathrm{CN})_{6}$ sebesar $8.2721 \times 10^{-6}$ $\mathrm{cm}^{2} / \mathrm{s}$. Dalam media aqueous, nilai koefisien difusi (D) yang dapat diterima adalah antara $10^{-5}$ dan $10^{-6} \mathrm{~cm}^{2} / \mathrm{s}$ (Bard and Faulkner, 2000). Oleh karena itu, elektrode pembanding $\mathrm{Ag} / \mathrm{AgCl}$ yang dibuat layak digunakan untuk analisis selanjutnya.

\section{Penentuan Waktu Deposisi Optimum}

Waktu deposisi optimum ditentukan untuk mengetahui waktu terbaik analit yang dianalisis terdeposisi di permukaan elektrode kerja. Voltamogram larutan standar Fe(III) 500 $\mathrm{ppb}$ yang sudah dikoreksi dengan voltammogram larutan blanko ditunjukkan pada Gambar 1, yang menunjukkan bahwa waktu deposisi optimum diperoleh pada 70 detik. Arus puncak mengalami peningkatan sebelum waktu deposisi optimum karena ion $\mathrm{Fe}(\mathrm{III})$ dalam larutan belum tereduksi sempurna menjadi $\mathrm{Fe}$ dan terdeposisi di permukaan elektrode kerja. Reaksi reduksi hanya terjadi pada lapisan difusi pada permukaan elektrode. Setelah waktu deposisi 
optimum, lapisan difusi pada permukaan elektrode kerja sudah jenuh dengan ion $\mathrm{Fe}$ sehingga arus puncak mengalami penurunan.

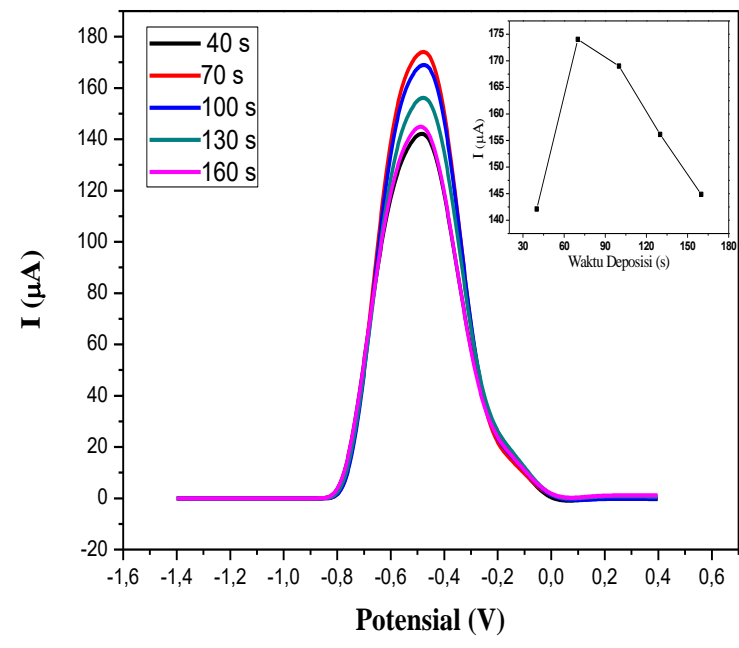

Gambar 1. Voltamogram larutan standar Fe(III) 500 ppb dengan variasi waktu deposisi.

\section{Penentuan Laju Pindai Optimum}

Data voltamogram laju pindai larutan standar $\mathrm{Fe}(\mathrm{III}) 500$ ppb ditunjukkan pada Gambar 2. Laju pindai optimum sebesar 10 $\mathrm{mV} /$ detik menunjukkan bahwa pada laju pindai tersebut telah tercapai kesetimbangan laju reaksi reduksi $\mathrm{Fe}(\mathrm{III})$ pada proses deposisi dan laju reaksi oksidasi menjadi $\mathrm{Fe}(\mathrm{III})$ kembali pada proses pelucutan (stripping) pada permukaan elektrode.

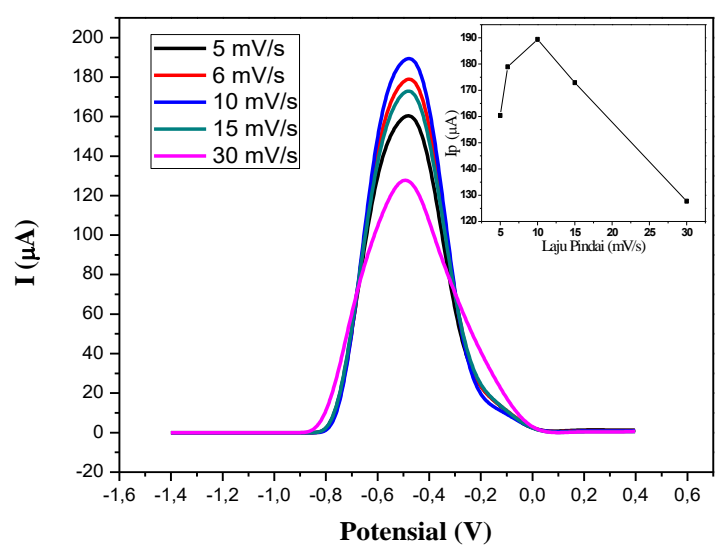

Gambar 2. Voltamogram larutan standar Fe(III) 500 ppb dengan variasi laju pindai

\section{Penentuan Potensial Deposisi Optimum}

Potensial deposisi yang diberikan pada elektrode kerja cakram platina bertujuan untuk mereduksi ion logam dalam larutan dan terdeposisi pada permukaan elektrode kerja. Voltamogram potensial deposisi larutan standar Fe(III) ditunjukkan pada Gambar 3. Pada teknik voltammetri pelucutan anodik, tahap deposisi akan mengalami reaksi reduksi. Untuk mereduksi ion logam, potensial deposisi yang diberikan harus lebih negatif dari potensial reduksi standar besi $\left(\mathrm{E}^{0} \mathrm{Fe}^{3+} / \mathrm{Fe}^{2+}\right.$ yaitu $+0.771 \mathrm{~V})$. Dari hasil optimasi, diperoleh potensial deposisi optimum sebesar $-0.47 \mathrm{~V}$.

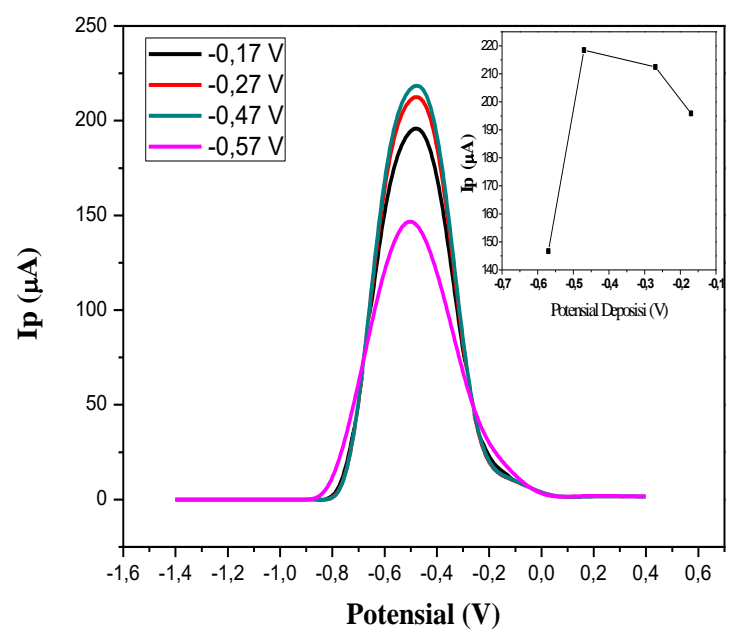

Gambar 3. Voltamogram larutan standar Fe(III) $500 \mathrm{ppb}$ dengan variasi potensial deposisi

Dari hasil optimasi tersebut menunjukkan bahwa reaksi reduksi $\mathrm{Fe}(\mathrm{III})$ menjadi $\mathrm{Fe}$ pada permukaan elektroda menghasilkan arus optimum jika diberikan potensial $-0,47 \mathrm{~V}$.

\section{Penentuan rentang konsentrasi linier}

Hasil pengukuran arus puncak larutan standar Fe(III) dari konsentrasi 5 ppb sampai $2500 \mathrm{ppb}$ menunjukkan rentang konsentrasi linier hanya pada rentang $50 \mathrm{ppb}$ sampai 500 $\mathrm{ppb}$, dengan nilai koefisien korelasi $\left(\mathrm{r}^{2}\right)$ sebesar 0.9954. Arus puncak pengukuran larutan konsentrasi lebih kecil dari 50 ppb tidak signifikan dengan kenaikan konsentrasi, demikian pula dengan hasil pengukuran larutan dengan konsentrasi yang lebih besar dari 500 ppb. Rentang konsentrasi linier menunjukkan hubungan linier antara konsentrasi dengan arus puncak yang dihasilkan, karena kenaikan arus puncak berbanding lurus dengan kenaikan konsentrasi. Kurva kalibrasi larutan standar $\mathrm{Fe}(\mathrm{III})$ ditunjukkan pada Gambar 4. 


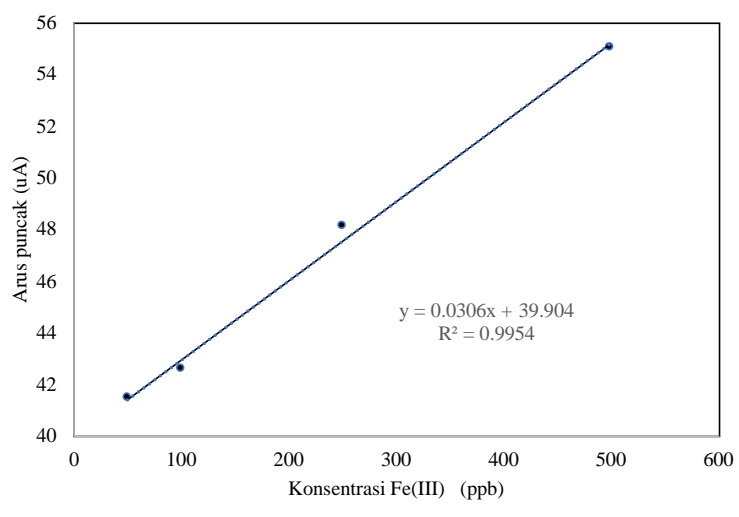

Gambar 4. Kurva kalibrasi larutan standar Fe(III)

\section{Penentuan limit deteksi}

Limit deteksi menunjukkan konsentrasi terkecil analit yang dapat terdeteksi oleh instrumen, yang berbeda dengan blanko. Jika kadar ion logam dalam sampel lebih rendah dari limit deteksi, maka akan sulit untuk membedakan antara arus puncak yang dihasilkan oleh blanko dengan arus puncak dari analit. Limit deteksi larutan standar $\mathrm{Fe}(\mathrm{III})$ berdasarkan hasil perhitungan sebesar $50.18 \mathrm{ppb}$.

\section{Penentuan keberulangan pengukuran}

Hasil pengukuran larutan standar Fe(III) 500 ppb sebanyak 10 kali memiliki nilai standard deviation 0.5744 , relative standard deviation 0.0181, coefficient variation $1.81 \%$, dan rasio Horwits 0.1019 . Nilai rasio Horwits yang kurang dari 2 menunjukkan hasil yang baik untuk keberulangan pengukuran (Horwitz and Albert, 2006). Data pengukuran arus puncak sepuluh larutan $\mathrm{Fe}(\mathrm{III})$ dengan konsentrasi yang sama ditunjukkan pada Gambar 5.

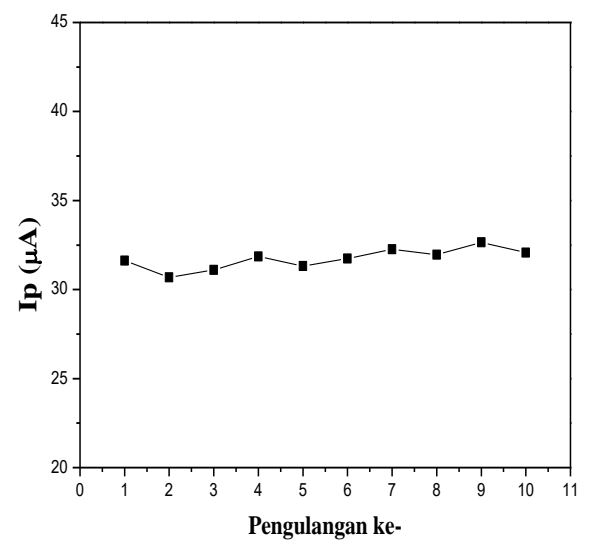

Gambar 5. Kurva keberulangan pengukuran larutan standar Fe(III) 500 ppb

\section{Penentuan persen perolehan kembali}

Persen perolehan kembali

menunjukkan akurasi (ketepatan) pengukuran instrumen terhadap nilai sebenarnya. Berdasarkan peraturan AOAC (1998), nilai persen perolehan kembali yang dapat diterima untuk pengukuran analit berada pada rentang $80 \%$ sampai $110 \%$. Dari hasil pengukuran tiga larutan standar $\mathrm{Fe}(\mathrm{III})$ konsentrasi $500 \mathrm{ppb}$ diperoleh persen perolehan kembali sebesar $100.26 \% \pm 0.27 \%$. Dengan demikian nilai tersebut dapat diterima.

\section{Penentuan kadar air dan logam Fe dalam sampel}

Berdasarkan hasil perhitungan, kadar air pada sayur pakcoy sebesar $92.34 \%$. Sampel yang sudah dihaluskan, selanjutnya didestruksi basah agar semua senyawa yang berikatan dengan logam yang ada di dalam sampel dapat terputus. Penentuan kadar Fe(III) menggunakan metode adisi standar. Kurva adisi standar pengukuran sampel ditunjukkan pada Gambar 6.

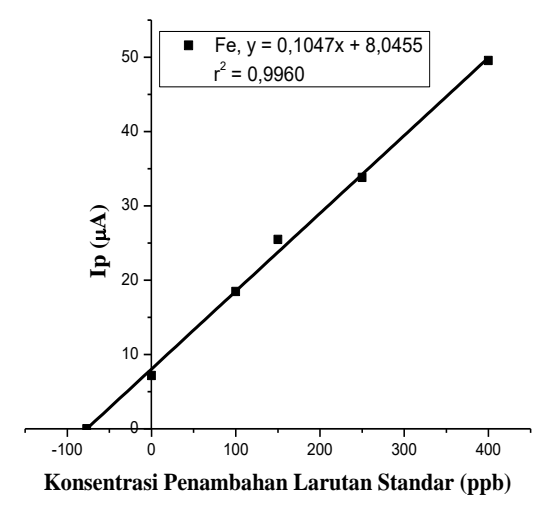

Gambar 6. Kurva adisi standar pengukuran Fe(III) pada sampel tanaman pakcoy

Berdasarkan persamaan garis yang diperoleh, kadar Fe(III) pada sampel tanaman pakcoy sebesar 3.82 \pm 0.29 ppm. Menurut Standar Nasional Indonesia (SNI) nomor 7387:2009 tentang Batas Maksimum Cemaran Logam Berat dalam Pangan, kadar Fe(III) yang diperbolehkan tidak melebihi 5.0 ppm. Dengan demikian, kadar $\mathrm{Fe}(\mathrm{III})$ tidak melebihi standar yang telah ditetapkan. Adanya logam berat $\mathrm{Fe}$ dalam sampel pakcoy disebabkan oleh penggunaan pestisida dan air yang digunakan untuk menyiram sayuran yang mengandung Fe. 


\section{SIMPULAN}

Pengukuran validitas larutan standar $\mathrm{Fe}(\mathrm{III})$ menggunakan teknik voltammetri pelucutan anodik pulsa diferensial ditunjukkan dengan nilai rentang konsentrasi linier larutan standar $\mathrm{Fe}(\mathrm{III})$ 50-500 ppb, dengan koefisien korelasi 0.9954 yang mendekati satu. Limit deteksi diperoleh 50.18 ppb. Keberulangan pengukuran memiliki rasio Howritz lebih kecil dari 2. Persen perolehan kembali $100.26 \% \pm 0.27 \%$. Sampel tanaman pakcoy memiliki kandungan $\mathrm{Fe}$ (III) sebesar $3.82 \pm 0.29$ ppm, sehingga dapat diketahui bahwa kadar $\mathrm{Fe}(\mathrm{III})$ dalam sampel tidak melebihi kadar maksimum yang diperkenankan.

\section{UCAPAN TERIMA KASIH}

Penulis mengucapkan terima kasih kepada Direktorat Penelitian dan Pengabdian kepada Masyarakat (DP2M), Kementerian Ristek Dikti melalui Hibah Penelitian Dasar Unggulan Perguruan Tinggi (PDUPT) Tahun 2018 No. Kontrak 171.59/UN14.4.A/LT/ 2018. Penulis juga menyampaikan terima kasih kepada Bapak I Made Sudika selaku pemilik kebun sayur tempat sampling.

\section{DAFTAR PUSTAKA}

Alloway BJ. 2013. Heavy Metal in Soils: Trace Metals and Metalloids in Soils and the Bioavailability. Berlin: Springer.

AOAC (Association of Official Analytical Chemist). 1998. Peer-Verified Methods Program Manual Policies and Procedures. Gaithersburg (US): AOAC International.
Arduini F, Calvo J.Q, Palleschi G, Moscone D, Amine A. 2010. Bismuth modified electrodes for lead detection. Trends Analytical Chemistry. 29(11): 1295-1304

Badan Standardisasi Nasional. 2009. SNI:7387 Batas Maksimum Cemaran Logam Berat dalam Pangan Jakarta (ID): BSN

Bard AJ, Faulkner LR. 2000. Electrochemical Methods: Fundamentals and Applications, $2^{\text {nd }}$ ed. New York (US): John Wiley \& Sons Inc.

Gunzler H, Williams A. 2001. Handbook of Analytical Techniques. Weinheim (DE): Wiley-VCH-Verlag.

Horwitz W, Albert RJ. 2006. The horwitz ratio (horrat): a useful index of method performance with respect to precision. Assoc.Off.Anal.Chem. 89(4): 1095-1109.

Miller JN, Miller JC. 2010. Statistics and Chemometrics for Analytical Chemistry, Sixth Edition. England (UK): Pearson Education Limited.

Priyono J. 2006. Kimia Tanah. Mataram (ID): Mataram University Press.

Settle F. 1997. Handbook of Instrumental Techniques for Analytical Chemistry. Arlington (US): National Science Foundation.

Zosky C. 2007. Handbook of Electrochemistry. Amsterdam (NL): Elsevier. 